Part of Journal of Research of the National Bureau of Standards, Volume 19, November 1937

\title{
SERVICE-TEST RESULTS OF TITANIUM-TREATED AND SILICON-TREATED STEEL RAILS
}

\author{
By G. Willard Quick
}

\section{ABSTRACT}

National Bureau of Standards Technologic Paper T241, published in 1923, gives the results of a cooperative investigation of the effects of titanium treatment on the properties of open-hearth rail steel as compared with those of silicon-treated rail steel. Rails from the titanium-treated heats and from comparison silicontreated heats were laid in the tracks of the Illinois Central Railroad Co. (now Illinois Central System) in 1921. The service results reported for these rails are given in this paper and show that for rails laid in heavy-traffic territory, a slightly larger percentage of titanium-treated rails remained in service after 15 years than of the comparison or silicon-treated rails.

\section{CONTENTS}

I. Introduction

II. Service records of titanium-treated and silicon-treated steel rails

III. Summary _. _....... 533

\section{INTRODUCTION}

In 1921 a cooperative investigation was begun with the Titanium Alloy Manufacturing Co., the Illinois Central Railroad Co., the Illinois Steel Co., and the Robert W. Hunt Co., to study the effect of titanium additions in open-hearth rail steel as compared with steel treated with ferrosilicon as a deoxidizer. Twenty heats were made to which ferrocarbon-titanium additions were made in the ladle, while ferromanganese additions were divided between the furnace and ladle. Twenty-three heats were made with additions of ferrosilicon and ferromanganese in the ladle.

Descriptions of the manufacture of the steel, the rolling and inspection of rails and results of laboratory tests on $A$ rails, including chemical analyses, metallographic examinations, and physical-property tests, were published in $1923 .^{1}$

The laboratory tests showed that the top ends of the $A$-rails from titanium-treated steel ingots were much less segregated than the top ends of $A$-rails from silicon-treated steel ingots. It was found, however, that piping, as shown by inspection of the top ends of the $A$-rails, was more prevalent in the titanium-treated than in the silicontreated steel. As a whole, there was not as much improvement in mechanical properties from titanium treatment as might be expected from the decreased segregation, and the improvement in the steel

1 George K. Burgess and G. Willard Quick. A comparison of the deoxidation effects of titanium and silicon on the properties of rail steel. Tech. Pap. BS 17, $581(1922-24) \mathrm{T} 241$. 
was confined largely to the upper portion of the ingot, the effects disappearing before the $B$-rail was reached. The results of the investigation were summarized in Technologic Paper 241 as follows:

1. A higher percentage of piped rails come from titanium- than from silicontreated rails, but the time of teeming affects the number of pipes. The greatest number of pipes were in rails from steel treated with the smaller amount of ferrocarbon-titanium per ton, and variations in the amount above this did not seem to affect the pipe.

2. The titanium-treated rails were harder to break and showed more uniform fractures in the drop test than those treated with ferrosilicon.

3. The titanium additions compared with the silicon additions had a marked effect in reducing the segregation of carbon at the top of the ingot. This improvement was approximately proportional to the titanium additions, but the effect falls off rapidly at the bottom ends of the $A$-rails.

4. Nitrogen determined by the Allen method decreases as the residual titanium in the steel increases. This indicates that less nitrogen is combined with iron and manganese, not that the nitrogen has been eliminated, but that it probably is combined with titanium or silicon.

5 . The addition of from 8 to 10 pounds of ferrocarbon-titanium per ton causes an immediate and appreciable drop in the amount of oxides reducible by carbon, while for additions of more than this amount the oxides reducible by carbon are entirely lacking.

6. Titanium treatment is shown by sulphur prints to lessen segregation of sulphur, particularly in the drop-test pieces, and in samples from the top ends of the $A$-rails, where this segregation is most prevalent in the silicon-treated rails. This condition was checked by etching specimens in boiling hydrochloric acid, which showed streaks in many of the silicon-treated pieces, whereas the pieces treated with titanium remained practically free from streaks.

7. Rail sections from the top of the ingots from titanium-treated heats were more uniform in hardness than those from similar positions in silicon-treated heats. This effect had entirely disappeared at the bottom of the ingot.

8. The results of tensile, impact, and endurance tests did not show as much improvement from titanium treatment as was expected from the decreased segregation. There was somewhat more uniformity in mechanical properties at the top ends of $A$-rails from titanium- than from silicon-treated heats. At the bottom ends of $A$-rails not much improvement was shown by titanium treatment.

9 . Steel treated with from 8 to 10 pounds of ferrocarbon-titanium per ton retains about 19 percent of the titanium and steel treated with from 10 to 13 pounds, about 33 percent, whereas the silicon-treated steel retains about 81 percent of the silicon. The smaller amount of titanium remaining in the steel treated with from 8 to 10 pounds of ferrocarbon-titanium per ton is retained in the form of violet inclusions, perhaps of titanium oxide and some of a lower nitrogen compound of titanium, and for treatments with larger amounts much more titanium is retained as similar violet inclusions, and, in addition, in the form of orange inclusions, probably a higher nitrogen compound of titanium.

10. In the titanium-treated steel the sulphide inclusions were more broken up and scattered than in the silicon-treated steel, and this effect is dependent upon the retention of titanium in the steel.

\section{SERVICE RECORDS OF TITANIUM-TREATED AND SILICON-TREATED STEEL RAILS}

According to the program of the investigation, 1,000 tons each of the titanium-treated and the silicon-treated steels, from the heats described in Technologic Paper 241, were laid in the tracks of the Illinois Central Railroad in 1921. The rails were $90 \mathrm{lb} 33 \mathrm{ft}$ ARA section 9020 .

All of the titanium-treated rails were laid in groups in heavy traffic, whereas only half of the silicon-treated rails were laid in heavy traffic, the other half in intermediate traffic. Recently, at the request of the National Bureau of Standards, A. F. Blaess, Chief Engineer, Illinois Central System (formerly Illinois Central Railroad 
Co.) furnished a report on the service of these rails over a period of 15 years. Service records on rails from 20 other titanium-treated heats and on rails from 92 other untreated heats, (not treated with titanium) over a period of 16 years, were also supplied. The complete report follows:

15.38 track miles of this rail (titanium treated) were laid in 1920 and 1921; 6.71 track miles of it have been removed for various reasons, mainly worn out on curves and removed in regular rail program.

Transverse fissures in titanium-treated rail and ordinary untreated of the same rollings compared:

\begin{tabular}{|c|c|c|c|c|c|}
\hline Treatment & $\begin{array}{l}\text { Date } \\
\text { rclled }\end{array}$ & Mill & $\begin{array}{l}\text { Weight and } \\
\text { section }\end{array}$ & $\begin{array}{c}\text { Number of } \\
\text { heats }\end{array}$ & $\begin{array}{c}\text { Transverse- } \\
\text { fissure } \\
\text { rails }\end{array}$ \\
\hline Titanium treated $\mathbf{a}_{\text {-. }}$ & $2-1920$ & Gary & $90-\mathrm{ARA}-\mathrm{A}$ & 20 & 7 \\
\hline Untreateda & $2-1920$ & .... do & $90-\mathrm{ARA}-\mathrm{A}$ & 92 & 177 \\
\hline Titanium treated.............. & 2-1921 & .....do do........ & $90-\mathrm{ARA}-\mathrm{A}$ & 20 & 0 \\
\hline Untreated & 2-1921 & ....._do_.... & 90-ARA-A & 23 & 8 \\
\hline
\end{tabular}

- These heats are additional to those described in Technologic Paper 241.

Comparison on basis of per 100 track miles (laid) per year:

Titanium treated ........ 3.5 transverse-fissure rails.

Untreated ............. 25.1 transverse-fissure rails.

Records were not kept separately of other kinds of rail failures, but no difference was noted. Both the treated and untreated rail have some corrugation and measurements of contours show very little difference in amount of wear.

In the 92 heats of untreated rail rolled in 1920,27 heats have been entirely without transverse fissures, and the test can hardly be regarded as conclusive as to the effect of the titanium treatment.

For the rails rolled in 1921 (Tech. Pap. 241), from titanium-treated and silicon-treated heats, the following additional data were furnished:

Titanium treated rail rolled and laid in groups at several locations in heavy-traffic territory.

Remaining in track at original locations

Untreated rail from same rolling laid in 1921 in groups at several locations, one-half tonnage in heavy-traffic territory and one-half in intermediate-traffic territory

Remaining in track at original locations, one-third in heavy-traffic territory and two-thirds in intermediate-traffic territory _......- 4.75

According to the report quoted above, 52.5 percent of the titaniumtreated rails, described in Technologic Paper 241, were removed for various reasons between 1921 and 1936, whereas during the same period, 64.5 percent of the untreated rails laid in heavy traffic were removed for various reasons.

\section{SUMMARY}

1. To supplement laboratory studies, service tests of titaniumtreated open-hearth steel rails and comparison silicon-treated steel rails, all prepared under careful supervision, were started in 1921, the rails being placed in the regular service lines of the Illinois Central Railroad Co.

2. Up to date, no transverse fissures have been reported in the rails from the 20 heats of titanium-treated steel and 8 transverse fissures in the comparison rails from the 23 heats of silicon-treated 
steel. However, in rails purchased independently by the Illinois Central Railroad Co. and installed a year previously, 1920, in similar service, 7 transverse fissures have been reported up to date in the rails from 20 heats of titanium-treated steel and 177 transverse fissures in comparison rails from 92 heats of steel not treated with titanium.

3. During 15 years of service in heavy traffic, 52.5 percent of the titanium-treated rails were removed for various reasons, whereas 64.5 percent of the comparison silicon-treated rails were removed during the same period.

Washington, August 12, 1937. 